\title{
He イオンビーム加工による表面粗さの改善
}

\author{
井上 徳 之*, 志 真 俊 夫**
}

\author{
Improvement in Surface Roughness by He Ion-Beam Machining
}

Noriyuki INOUE* and Toshio SHIMA**

\begin{abstract}
Ion-beam machining has been investigated for its effect in decreasing surface roughness, and it has already been reported that low surface roughness can be obtained by low-energy argon ion-beam machining. In this study, lowmass helium ions were used to decrease the roughness of a mirror finished SKD 1 (high chromium-high carbon steel) surface. The results obtained were as follows : (1) A greater decrease in surface roughness was obtained with helium ion-beam machining than with low-energy argon ion-beam machining. (2) There is an optimum machining condition for decreasing the surface roughness, and the lowest surface roughness ( $6 \mathrm{~nm} R_{\max }$ ) obtained at a beam energy of $2 \mathrm{keV}$, a beam current density of $4 \mathrm{~A} / \mathrm{m}^{2}$ and a beam angle of $70^{\circ}$. (3) The decrease in surface roughness is obtained within the oxide layer (about $0.03 \mu \mathrm{m}$ ). (4) The mechanism of the decrease in the surface roughness is discussed in terms of the knock-on cascade model.
\end{abstract}

Key Words : Ion-beam Machining, Surface Roughness, Block Gauge, Herium Ion, Surface Finish

\section{1. 緒言}

イオンビーム加工は，セラミックスや半導体などの高 脆材料の超微細加工として用いられている。加工物の表 面粗さは機械的特性を制御するための重要な因子である。 一般に，イオンビーム加工は加工物の表面粗さを増大さ せてしまう。イオンビーム加工における表面粗さについ ては加工条件による影響が報告されており ${ }^{1) ， 2) ， こ れ に ~}$ 基づき低イオンエネルギーでの表面粗さが減少する可能 性が検討されている ${ }^{3)}$ 。

本研究ではイオンの質量に注目し，ヘリウムイオンを 用いることにより, 表面粗さをさらに減少させる可能性 とその機構について検討した。

\section{2. 実験方法}

\section{1 供試材料}

加工物は，ブロックゲージに用いられる SKD 1（高 クロム高炭素鋼）である。加工物表面はダイヤモンドラッ ピングにより約 $10 \mathrm{~nm} R_{\max }$ に鏡面仕上げされている。 なお，ラッピングではこれ以下の表面粗さを得るのは非 常に困難である。

\section{2 イオンスパッ夕加工}

イオンスパッタ加工にはイオン入射角を制御しながら 試料表面を均一（直径 $70 \mathrm{~mm}$ の範囲）に加工できる, カウフマンタイプのイオン源を持つイオンスパッタ加工

* 東海大学大学院（宁259-12 神奈川県平塚市北金目1117） Graduate School, Tokai Univ. (1117, Kita-Kaname, Hiratsuka-shi, Kanagawa 259-12)

** 東海大学工学部（干259-12 神奈川県平塚市北金目1117） Fac. of Eng., Tokai Univ. (1117, Kita-Kaname, Hiratsuka-shi, Kanagawa 259-12)
装置を用いた（図 1 )。加工物表面の一部をマスクして 試料ステージに取り付ける。これは未加工部と加工部と の段差より加工深さを測定するためである。そして，試 料ステージを水平面から垂直面まで回転させることによ りイオン入射角 $\theta$ を制御した。ここで， $\theta$ はイオンが加 工物表面に垂直に入射する場合を $0^{\circ}$ とした。なお，試 料ステージは水冷している。

実験は, イオンエネルギー $E$, イオン電流密度 $D$, イオン入射角 $\theta$, 加工時間 $t$ のイオン照射条件を変化さ せて行った。

\section{3 加工量およひ表面粗さの測定}

加工量および表面粗さの測定には夕リステップ（最大 倍率 : $10^{6}$ 倍，ランク・テーラーホブソン社）を用いた。 加工量は加工深さにより表した。表面粗さは加工物表面 につけた 2 個所のマイクロビッカース圧痕を目印にして,

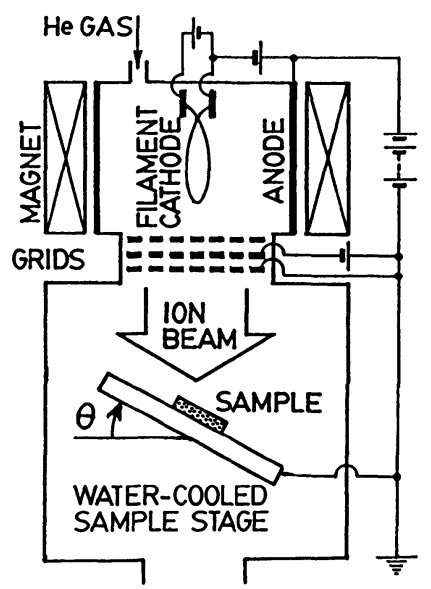

Fig. 1 Schematic diagram of ion-beam machining apparatus. 


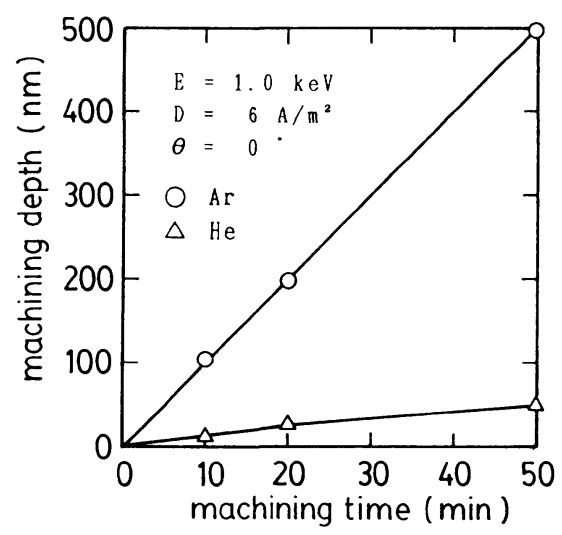

Fig. 2 Change of machining depth by argon and herium ion under same machining condition.

同じ箇所での変化を測定した。また，オージェ分光分析 により加工物表面の酸素濃度変化を調べた。

\section{3．実験結果および考察}

\section{1 ヘリウムのイオンエネルギー}

図 2 はへリウム入射イオンとアルゴンイオンの同一加 工条件における加工深さを示している。両者の加工深さ を比較してみると, ヘリウムはアルゴンの約 10 分の 1 になっている。このことよりへリウムの入射イオンェネ ルギーは非常に低いことがわかる。

また, 両者のエネルギー伝達係数 ${ }^{5)}\left[\gamma=4 M_{1} M_{2} /\right.$ $\left.\left(M_{1}+M_{2}\right)^{2}\right]$ より求めたへリウムの入射エネルギーは アルゴンの場合の約 4 分の 1 程度になっていることより, 衝突時の入射イオンェネルギー比がそのままスパッ夕比 にならないことあ示している。この理由についてはへリ ウムのイオン半径が小さいために生ずるチャネリング効 果と, ヘリウム入射イオンにより形成される衝突カスケー ドのエネルギーが非常に低いことに起因していると考え られる。

\section{2 イオンエネルギーおよひイオン電流密度の影零}

図 3 はイオン電流密度 $4 \mathrm{~A} / \mathrm{m}^{2}$, イオン入射角 $0^{\circ}$ と して，イオンェネルギーを $1 ， 1.5,2 \mathrm{keV}$ 変化させ た場合の表面粗さの変化を示している。表面粗さはいず れのイオンエネルギーにおいてあ加工初期に減少してい る。そしてその減少傾向はイオンエネルギーが低くなる につれアルゴンの場合と同様に遅い時期に現れている。 このうち最あ減少した表面粗さは，イオンエネルギー $1.5 \mathrm{keV}$ で表面粗さは約 $7 \mathrm{~nm} R_{\max }$ である。さらに加工 を続けた場合表面粗さはいずれる增加している。

図4は $1.5 \mathrm{keV}, 0^{\circ}$ として，イオン電流密度を 2 , $4,6 \mathrm{~A} / \mathrm{m}^{2}$ に変化させた場合の表面粗さの変化を示 している。イオン電流密度の大きい $6 \mathrm{~A} / \mathrm{m}^{2}$ の場合は

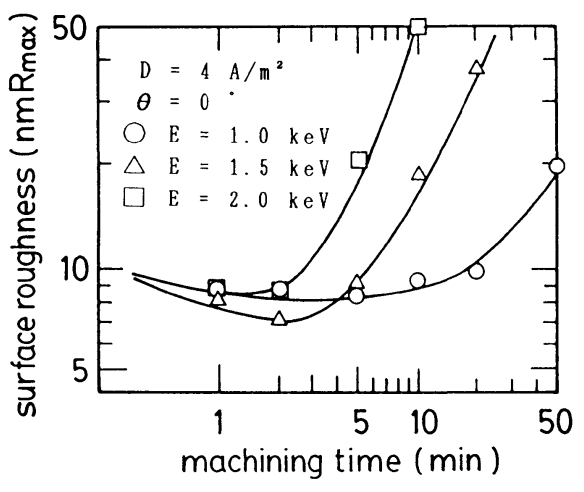

Fig. 3 Effect of ion energy on surface roughness.

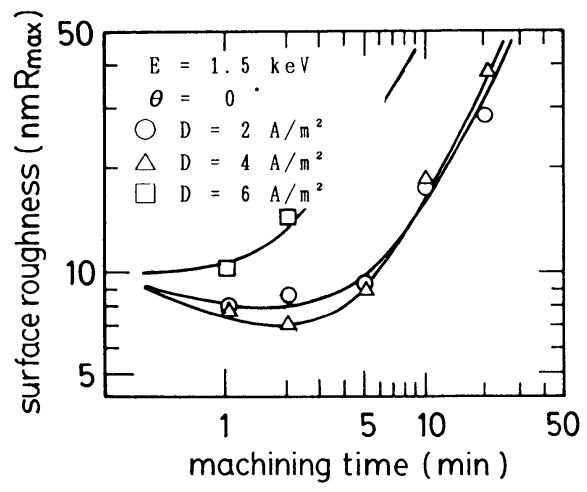

Fig. 4 Effect of ion current density on surface roughness.

表面粗さはほとんど変化していないが, イオン電流密度 の小さい $2 \mathrm{~A} / \mathrm{m}^{2}$ の場合には $4 \mathrm{~A} / \mathrm{m}^{2}$ と同程度に減少 している。

以上のことより表面粗さを減少させるには，アルゴン イオンの低エネルギーの場合と同様に, 最適なイオンエ ネルギー, イオン電流密度が存在することがわかる。

\section{3 イオン入射角の影輩}

図 5 は図 3 の加工条件のうち，イオン入射角を $70^{\circ}$ に した場合の表面粗さの変化を示している。図よりイオン 入射角の効果が現れ, 表面粗さはいずれも $0^{\circ}$ の場合よ り減少しているが, イオンェネルギーの高い $2 \mathrm{keV}$ 方 が $1.5 \mathrm{keV}$ より表面粗さは減少している。この場合に, 表面粗さ約 $6 \mathrm{~nm} R_{\max }$ が得られた。この値は今までの 実験結果では得られなかった最小の表面粗さである。

図 6 は図 4 の加工条件のうち, イオン入射角を $70^{\circ}$ に した場合の表面粗さの変化を示している。この場合表面 粗さは $4 \mathrm{~A} / \mathrm{m}^{2}$ ではイオン入射角の効果が現れている が, 他の $2,6 \mathrm{~A} / \mathrm{m}^{2}$, ではイオン入射角の効果は特に 現れていない。また，図5においてイオンェネルギーの 違いによる表面粗さはあまり違わないのに対し, この図 のイオン電流密度では $0{ }^{\circ}$ の場合と比べて, それらの差 


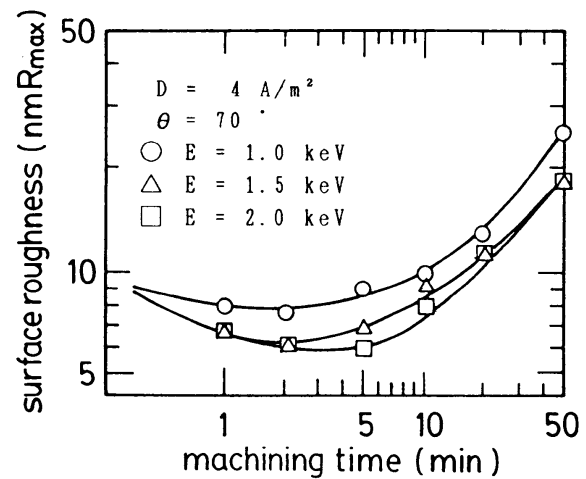

Fig. 5 Effect of ion energy on surface roughness at 70 degrees.

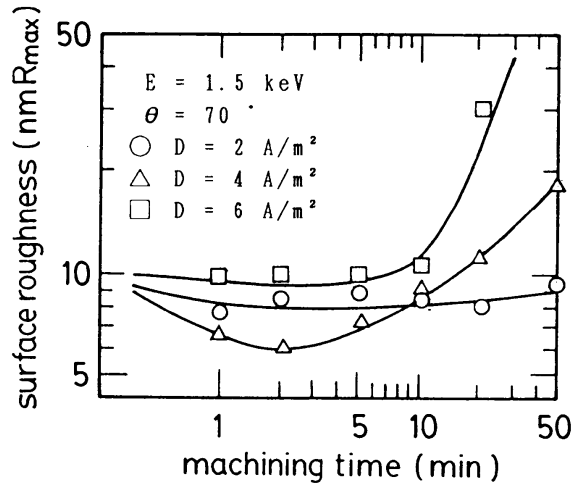

Fig. 6 Effect of ion current density on surface roughness at 70 degrees.

が大きく現れている。このことより，イオンの斜め入射 によって入射イオン量が少ない場合には，その多少が， より顕著に表面粗さに影響することがわかる。これは主 にへリウムのイオン径が小さいために生ずる表面原子と の衝突確率の影響と考えられる。

図 7 に加工前の表面粗さと改善された表面粗さ $6 \mathrm{~nm}$ $R_{\max }$ の表面形状 $\left(E=1.5 \mathrm{keV}, D=4 \mathrm{~A} / \mathrm{m}^{2}, \quad \theta=70^{\circ}\right)$ を示している。

\section{4 イオンスパッタ加工の表面粗さ隇少機構}

図 8 (a)にヘリウムイオンを使用した場合の加工物表 面形状の山と谷, すなわち凸部と凹部の凸部上端よりの 加工深さの変化の一例を示している。この両者の差は表 面粗さを表している。図より, 加工初期に凸部の加工深 さは増加するが, 凹部の加工深さはほとんど変化しない ため, その差が減少し $10 \mathrm{~min}$ 加工付近で最小になり, 表面粗さは最も減少している。その後の加工ではその差 は増加している。

図 8 (b) はアルゴンイオンの場合で, 同じく凸部と凹 部の凸部上端よりの加工深さの変化を示している。この 場合, 加工初期には凸部と凹部の加工深さの差はほとん

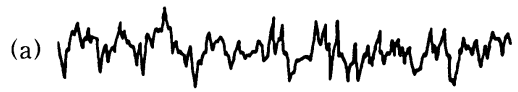

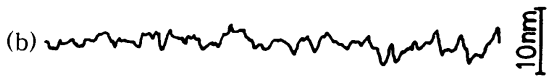

Fig. 7 Improved surface profile.

(a) before machining

(b) the smallest improed surface profile after $5 \mathrm{~min}$ machining
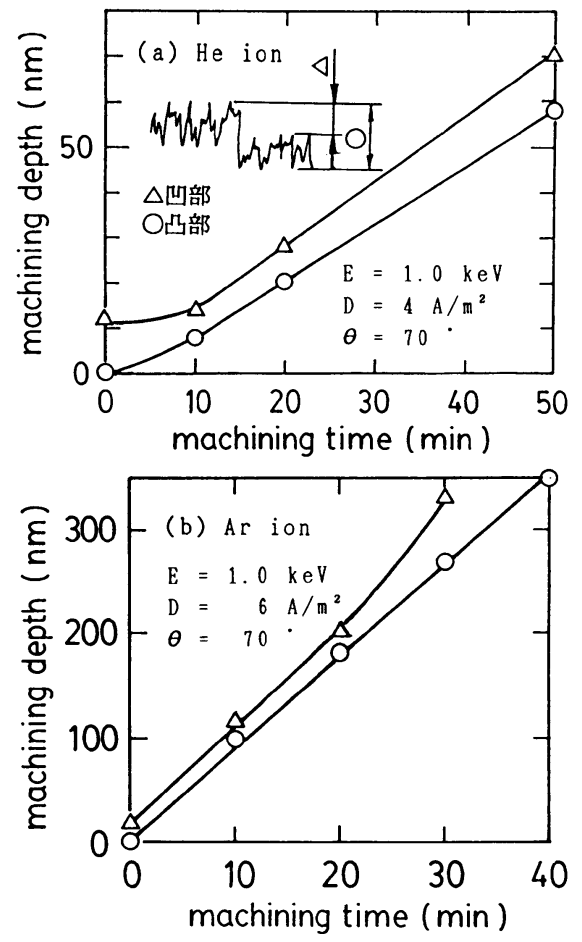

Fig. 8 Change of machining depth in upper and lower part of surface shape.
(a) herium ion
(b) argon ion

ど変わらず，その後はへリウムと同様に増加している。

以上の結果より, 表面粗さの減少機構は次のように考 えられる。表面粗さを減少させるためには凹部をあまり 加工せずに凸部を加工することが必要である。一般にス パッタリングの機構は, 入射イオンのエネルギーが固体 内で衝突カスケードを形成し，そのうち表面原子に達し た衝突カスケードのエネルギーがその結合エネルギーを 切り離すのに十分なときスパッ夕されると考えられてい る ${ }^{6)}$ 。それゆえ，表面原子がスパッ夕されるまでの衝突 カスケードが長いほどェネルギーは減少しスパッ夕は起 こりにくくなる。このことは, イオンの衝突筒所から表 面までの距離が短いほどスパッタされやすいと考えられ る。

以上のことより，凸部と凹部の衝突カスケードについ 
(a)

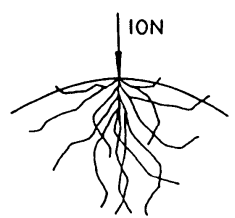

( b )
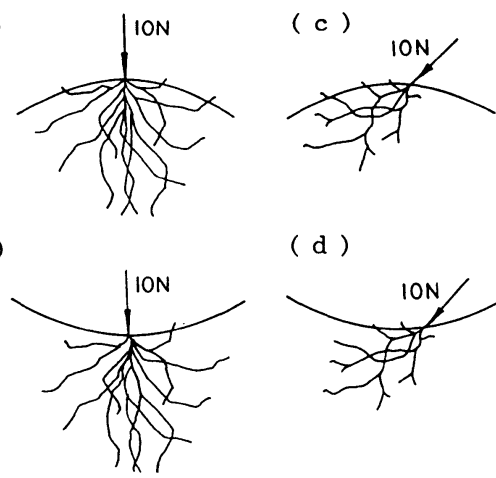

( d )

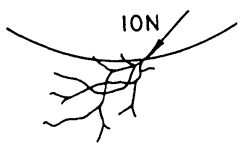

Fig. 9 Model of knock-on cascade in convex and concave parts.

(a, b) perpendicular incident ion

(c, d) oblique incident ion

て比較した場合，モデル図9 (a) (b) に示すように, 衝突 カスケードは凸部では表面に達しやすく, 凹部では達し にくい。このような機構で, 凸部, 凹部ともスパッ夕率 がほとんど同じ酸化層である場合には, 凸部が優先的に 加工されたと考えるとモデル図10 (a) に示すように図 8 (a)において表面粗さが減少することが説明できる。なお， オージェ分析により加工物表面には酸化層が形成され,

その厚さは約 $0.03 \mu \mathrm{m}$ であることが確認された。

また, 図8 (b)において加工初期に, 表面粗さがほと んど変化しなかったのは, 凸部と凹部のスパッ夕がほと んど同程度に行われたことを示している。このことは,

入射イオンェネルギーが高くなると加工物表面に達する 衝突カスケードェネルギーも当然増加し, それが凹部に おいてあ表面原子を切り離すのに，より十分であると考 えると, 衝㔖カスケードの長さの影響がなくなり, 凸部 と凹部がほとんど同程度に加工されることが説明できる (モデル図10 (b) 参照)。

さらに，斜め入射の場合に垂直入射より表面粗さが減 少するのは, モデル図 9 (c) (d) に示すように, 垂直入射 の場合より衝突カスケードは凸部, 凹部とも, より表面 部分に集中するが，凸部の衝突カスケードは極端に表面 に達しやすくなり，凸部がより加工されるためと考えら れる。

\section{4. 結言}

鏡面加工したSKD 1 にヘリウムイオンを用いてイオ ンスパッ夕加工を行い, 表面粗さの改善に関し次の結果 が得られた。

(1) 質量の小さいヘリウムイオンを用いることにより, 表面粗さをアルゴンの低イオンェネルギーの場合よりさ らに減少させることができた。

(2) 表面粗さを減少させるためには, 加工前の表面粗さ (a)
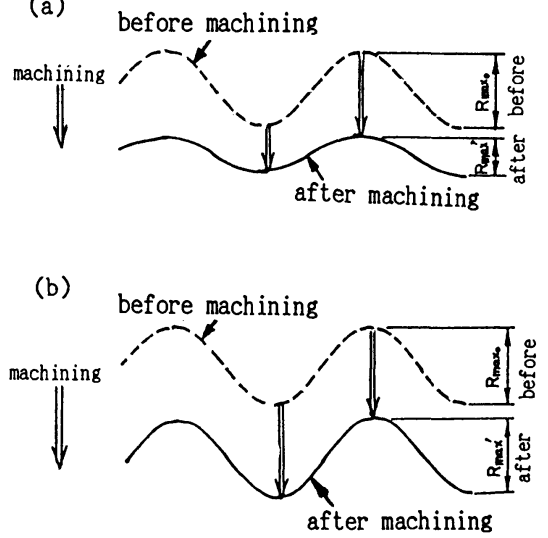

Fig. 10 Model of change in surface roughness. (a) optimum machining condition (b) non-optimum machining condition

に応じた最適なイオンエネルギー, イオン電流密度, イ オン入射角があり， $2 \mathrm{keV}, 4 \mathrm{~A} / \mathrm{m}^{2} ， 70^{\circ}$ で最小の表 面粗さ（約 $5 \sim 6 \mathrm{~nm} R_{\max }$ ) が得られた。

（3）オージェ分析結果より，酸化層内（約 $0.03 \mu \mathrm{m}$ ）で 表面粗さが減少していることがわかった。

(4) 表面粗さが減少する機構について, 凸部と凹部の加 工量変化と衝突力スケードモデルなどにより解明を試み た。

(5) 同一加工条件におけるへリウムの加工量はアルゴン の 10 分の 1 と非常に小さく, また, 両者の入射イオン エネルギー比がそのままスパッ夕比にならない。

なお, 表面粗さを変化させることなく, 酸化層（加工 変質層）を除去することあ可能である。

\section{謝辞}

終わりにあたり, 表面粗さ測定にご協力いただいた東 海大学工学部光学工学科 横田英嗣教授, 試料の提供を いただいた黒田精工(株)の川端 実氏および諸賢，オー ジェ分析をしていただいた㫼ミヨ夕の大矢頼武氏，白 鳥典彦氏，沖 恭一氏に感謝します。また，実験に協力 された東海大学卒業生清水啓一, 柴崎 亘, 内藤一成の 諸君に感謝する。

(1992-6-30 受理)

\section{文献}

1 ) 志真俊夫, 井上徳之; 精密工学会誌, 54, 896 (1988)

2) T. Shima, N. Inoue ; Precision Engineering, 12, 157 (1990)

3 ) 志真俊夫, 井上徳之; 東海大学工学部紀要, 査読終了掲載 待 (1992)

4) Y. Nishi, N. Inoue, K. Watanabe, T. Morishita, T. Shima ; J. Mater. Sci. Lett., 6, 63 (1978)

5 ) 金原 粲 ; スパッタリング現象, p.46（東京大学出版会, 1984)

6) P. Sigmund ; Phys. Rev., 184, 383 (1969) 